\title{
CRÔNICAS DO ESTADO NOVO: GRACILIANO RAMOS E A REVISTA CULTURA POLÍTICA
}

\author{
NEW STATE CHRONICLES: \\ GRACILIANO RAMOS AND THE MAGAZINE CULTURA POLÍTICA
}

\author{
Francisco Fábio Pinheiro de Vasconcelos ${ }^{1}$ \\ Luciene Souza Santos ${ }^{2}$
}

\begin{abstract}
Resumo: As crônicas publicadas por Graciliano Ramos e reunidas postumamente em dois livros Linhas tortas e Viventes das Alagoas são a viga mestra da investigação deste artigo. $\mathrm{O}$ escritor alagoano se serviu do gênero cronístico em três momentos distintos. Primeiro como laboratório literário na sua primeira viagem ao Rio de Janeiro, depois na sua volta a Alagoas e por fim quando dela se serve como meio de sobrevivência. Em Viventes das Alagoas aparecem os textos produzidos para a revista Cultura Política, publicação subordinada ao Departamento de Imprensa e Propaganda da ditadura Vargas. Averigou-se essa agência e seu papel, além de perquirir as circunstâncias que levaram Graciliano Ramos a colaborar por quatro anos em um Aparelho Ideológico do Estado, regime que o encarcerou. Para alguns estudiosos, necessidade econômica, para outros, alinhamento político-ideológico. Detectou-se a ironia e o tom acrimonioso que desconstruía o projeto de nacionalidade estado-novista e, portanto, esvaziam-se as insinuações de emparelhamento do escritor ao projeto cultural da revista.
\end{abstract}

Palavras-chave: crônica, Estado Novo, autonomia intelectual, discurso irônico.

Abstract: The chronicles published by Graciliano Ramos and posthumously assembled in two books Linhas tortas and Viventes das Alagoas are the cornerstone of the investigation of this article. The writer from Alagoas made use of the chronistic genre at three different times. First as a literary laboratory on his first trip to Rio de Janeiro, then on his return to Alagoas and finally when it worked as a mean to survive. The texts in Viventes das Alagoas were produced to the Cultura Politica magazine, a publication subordinated to the Press and Publicity Department of the Vargas dictatorship. This agency and its role were investigated, as well as the circumstances that led Graciliano Ramos to collaborate for four years in an ideological apparatus of the State, a regime that imprisoned him. For some scholars economic necessity, for others political-ideological alignment. The irony and acrimonious tone that deconstructed the project of state-novice nationality was detected and, therefore, the insinuations about the writer's pairing with the magazine's cultural project are emptied.

Keywords: chronicle, New State, intellectual autonomy, ironic discourse.

\footnotetext{
${ }^{1}$ Universidade Estadual de Feira de Santana. E-mail: ffabiovasc@ gmail.com

2 Docente do Mestrado Profissional em Letras (PROFLETRAS) da Universidade Estadual de Feira de Santana. E-mail: lucienesantoz@gmail.com
} 


\section{Introdução}

A relação entre o escritor Graciliano Ramos e o Estado Novo, através da colaboração na revista Cultura Política tem sido tratada como um tema polêmico e, por isso, muitas vezes permaneceu silenciado, adormecido. Não é inverdade afirmarmos que ele foi minimamente esquadrinhado pelos estudiosos da obra do escritor alagoano. Assim, um dos nossos objetivos é melhor compreender a relação entre o escritor e o Estado Novo. Dizendo de forma mais explícita: entender como o conjunto de textos publicados pelo escritor/intelectual, numa revista ligada ao Estado Novo, subordinada ao Departamento de Imprensa e Propaganda, respondeu ao Estado ditatorial e suas estruturas coercitivas.

Tencionamos analisar se o autor de Vivente das Alagoas usa, na sua escrita, investido de um narrador, a estratégia da sobrevivência, isto é, o narrador dos textos não promove a proposta ideológica estado-novista, mas também não denuncia o estado repressivo e autoritário pelo qual o autor das crônicas fora encarcerado. Ou ainda o contrário disso: se o narrador dessas crônicas torna-se um dissidente, aponta, valendo-se de recursos literários, como a ironia, os abusos de poder, o falseamento da recuperação da realidade brasileira de tom ufanista, as perseguições sofridas por aqueles que se opuseram ao regime ditatorial, além de se utilizar desse espaço como meio de comunicação com o público leitor.

Sabemos, desde já, que postumamente se deu a publicação de uma Literatura de Testemunho, Memórias do Cárcere, publicada em 1953, na qual o narrador-autor rompeu as comportas do arbítrio e da opressão e descortinou as mazelas e humilhações, às quais, não apenas ele, mas centenas de brasileiros foram submetidos pelo regime de exceção. Entretanto, nosso foco de estudo são as crônicas publicadas na revista Cultura Política.

São vinte e cinco crônicas publicadas na Cultura Política ${ }^{3}$ entre março de 1941 e agosto de 1944, nas seções intituladas Quadros e costumes do Nordeste; Quadros e costumes regionais ou Quadros regionais.

\footnotetext{
${ }^{3}$ As crônicas foram publicadas postumamente em 1962. Vinte e duas crônicas formam o corpo principal do livro Vivente das Alagoas. As outras duas crônicas - A viúva Lacerda e Booker Washington, foram fixadas no outro livro de crônicas intitulado Linhas Tortas. Uma outra, a vigésima quinta, "Uma visita inconveniente" ainda não foi inserida em nenhum dos dois livros. A catalogação das crônicas publicadas na revista Cultura Política foram também estabelecidas por Yêdda Dias Lima e Zenir Campos Reis no livro Catálogo de Manuscritos do Arquivo Graciliano Ramos, (1992). A partir de agora, continuaremos a usar a 8 ed. de Linhas tortas e a 10 ed. de Viventes das Alagoas: quadros e costumes do Nordeste. Entretanto, suprimiremos nas referências autor e ano, mas traremos as iniciais L. t. e V. A. para identificar os respectivos livros.
} 


\section{O estado Novo e os aparatos culturais: o caso da revista Cultura Política}

Comecemos lembrando que uma das principais preocupações do Estado Novo se concentrou na construção de estratégias político-ideológicas que o legitimassem frente à opinião pública, através da propaganda sistemática, sem, contudo, abrir mão, quando lhe foi conveniente, e quase sempre o fora, de usar seu poder coercitivo através da violência física.

Uma das mais eficientes estratégias postas em prática pelo regime foi a criação de elaboradíssimos aparatos culturais próprios que estreitassem as relações entre o Estado e a sociedade. Esses mesmos aparatos prestavam-se eficientemente à tarefa de difundir para a sociedade a sua visão política, ideológica e governamental e assim, legitimar-se frente à nação. Para confirmar o que estamos a atestar, nos valemos da voz de Velloso (1982, p. 72), cujo estudo assevera que: “[...] nenhum governo anterior teve tanto empenho em se legitimar e nem recorreu a aparatos ideológicos tão sofisticados, conforme o fez o novo regime".

Portanto, a criação da revista Cultura Política integra um grande conjunto de realizações na área da política cultural do Estado Novo, funcionando como um mecanismo fundamental na difusão política e ideológica desse regime. Estava ligada ao Departamento de Imprensa e Propaganda (DIP $)^{4}$, e este, por sua vez, se vinculava diretamente às ordens do presidente Getúlio Vargas. O DIP era na definição de Antelo (1984, p. 5) “a voz delegada de Getúlio" e por ser uma poderosa agência do Estado destinava-se a centralizar a publicidade oficial e chamava para si a responsabilidade de supervisionar os mais diversos meios de comunicação de massa. Em outros termos, o DIP tinha uma dupla face, isto é, de um lado, procurava difundir amplamente a imagem do novo regime e de outro, combatia a veiculação de todas as mensagens que lhes fossem contrárias. Como nos assegura Gomes:

[...] Esta poderosa agência (DIP), supervisiona os mais variados instrumentos de comunicação de massa, além de encarregar-se da produção e da divulgação do

\footnotetext{
4 O DIP foi criado por decreto presidencial em dezembro de 1939, seu objetivo era difundir a ideologia do Estado Novo junto às camadas populares. Contudo, sua origem remontava a um período anterior. Em 1931 foi criado o Departamento Oficial de Publicidade, e em 1934 o Departamento de Propaganda e Difusão Cultural (DPDC). Já no Estado Novo, no início de 1938, o DPDC transformou-se no Departamento Nacional de Propaganda (DNP), que finalmente deu lugar ao DIP. O DIP congregava os setores de divulgação, radiodifusão, teatro, cinema, turismo e imprensa. Cabia-lhe coordenar, orientar e centralizar a propaganda interna e externa, fazer censura ao teatro, cinema e funções esportivas e recreativas, organizar manifestações cívicas, festas patrióticas, exposições, concertos, conferências, e dirigir o programa de radiodifusão oficial do governo. Vários estados possuíam órgãos filiados ao DIP, os chamados "Deips". Essa estrutura altamente centralizada permitia ao governo exercer o controle da informação, possibilitando-lhe total domínio da vida cultural do país. Na imprensa, a uniformização das notícias era garantida pela Agência Nacional. O DIP as distribuía gratuitamente ou como matéria subvencionada, dificultando assim o trabalho das empresas particulares.
} 
noticiário oficial. Suas seis seções demonstram bem o grau de intervenção do Estado Novo nos processos sociais de comunicação: propaganda; radiodifusão; cinema e teatro; turismo; imprensa; serviços auxiliares, como financiamento de projetos etc. $\mathrm{O}$ DIP, portanto, materializa o grande esforço empreendido, durante o Estado Novo, para controlar os instrumentos necessários à construção e implementação de um projeto político-ideológico que se afirmasse como socialmente dominante (GOMES, 1982, p. 110).

Para espraiar um pouco mais nossa reflexão e entendimento sobre essa agência, é oportuno escutarmos novamente as palavras de Gomes (1996):

[...] difundir amplamente a imagem do novo regime que se instalara em novembro de 1937 e de combater a veiculação de todas as mensagens que lhe fossem contrárias. Para tanto, o órgão deveria ser um grande mecanismo de promoção da figura do chefe de Estado, das autoridades que o cercavam e das iniciativas políticas então implementadas, produzindo e divulgando o noticiário oficial e supervisionando todos os instrumentos de comunicação de massa (GOMES, 1996, p. 126).

Como estamos a perceber, a importância dessa agência reside em produzir e divulgar o noticiário oficial, ventilar o projeto político (autoritário) do regime e ao mesmo tempo manter a vigilância castradora que visa o embargo de notícias ou manifestações diversas que contrariassem a ordem vigente.

Criada em 1939, com ramificações em diversos estados (Deips), a referida agência era dirigida pelo jornalista sergipano Lourival Fontes. O DIP era a realização concreta de um instrumento que ventilava o viés político-ideológico do regime, ao mesmo tempo em que marcava presença, sufocando e silenciando os discursos contrários ao Estado Novo. A imprensa, através de jornais e revistas, era tida como o setor mais eficiente da agência.

[...] A centralidade da seção de imprensa nesse conjunto é evidente, já que era o lócus de produção principal dos elementos do discurso que deveriam ser trabalhados e transmitidos por todos os demais meios de comunicação, segundo suas linguagens particulares e recursos tecnológicos específicos (GOMES, 1996, p. 126).

Sobre a censura praticada pelo DIP, Garcia (1982) nos esclarece que o DIP se encarregou de toda atividade censória em relação ao teatro, ao cinema, às funções recreativas e esportivas. Ademais, a radiodifusão, a literatura social e política e a imprensa eram triados pala sua "peneira". Sabemos que a imprensa foi tratada com especificidade pela Carta de 37, que, considerando-a uma "função de caráter público", impediu a recusa à inserção de comunicação do governo, e previu sua regulamentação por lei especial. A censura à imprensa se fazia através de comunicações verbais, normalmente por telefone, quando eram passadas as notícias que não poderiam ser divulgadas, sem comentários ou apenas com comentários favoráveis e aqueles de inclusão obrigatória. Em diversas ocasiões, foram destacados censores para cada jornal, incumbidos de verificar os originais antes de serem enviados às oficinas. As notícias da Agência Nacional (que também irradiava a Voz do Brasil, das 20 às 21 horas) 
chegavam prontas, com especificações sobre a página em que deveriam ser inseridas, com que destaque e até os tipos que deveriam ser utilizados. No que se refere à censura de programas radiofônicos, letras de música, cinema, teatro e outras representações e apresentações públicas, a censura era feita previamente, com autorização ou interdição.

Velloso (1982, p. 73) nos revela que: "o discurso veiculado pelo conjunto dos meios de comunicação tem a sua matriz na imprensa escrita". Entretanto, sabemos que não é possível menosprezar o papel eficaz que cumpriram os outros meios de comunicação na difusão do viés ideológico do regime a exemplo da radiodifusão, do cinema, do teatro e do turismo.

Para produzir e divulgar o projeto político-ideológico que se afirmasse socialmente dominante, o Estado Novo, através do DIP, fez nascer algumas revistas que serviam como fontes de produção da ideologia do regime e se destinavam também a esclarecer e divulgar para o público as transformações pelas quais o país atravessava, via obras empreendidas por iniciativa governamental, além de esclarecer os conteúdos da proposta cultural do Estado Novo. São exemplos desse esforço às revistas Ciência Política, Estudos e conferências, Cultura Política: estudos brasileiros.

A Cultura Política estava sob a direção de um dos principais ideólogos do regime de 1937, o professor Almir de Andrade. A revista teve seu primeiro número lançado em março de 1941 e o último em outubro de 1945, totalizando cinquenta números. Dissolvida a Agência Nacional, Almir de Andrade ainda conseguiu organizar e imprimir três números, os quais saíram em agosto, setembro e outubro de 1945.

A Cultura Política, segundo o próprio Almir de Andrade, no editorial de abertura, tinha duas missões fundamentais: definir e esclarecer, para um grande público, o rumo das transformações que se vinham processando na política, na economia, nas artes, nas letras, nas ciências etc., e discutir constantemente os valores que orientavam tais mudanças. Por ser a Cultura Política a revista oficial do regime getulista, todas as suas edições se iniciavam com a reprodução de um discurso do presidente Vargas ou com um texto de Almir de Andrade, cujo teor era o de ressaltar o presidente e seu regime. A revista podia ser encontrada nas principais bancas de jornal do país por um "preço simbólico". Segundo Lima (2001, p. 87), "a revista Cultura Política tem a missão de dominar as diversas faces de uma política cultural de

\footnotetext{
${ }^{5}$ Segundo depoimento de Almir de Andrade (1985, p. 23) o custo da revista girava em torno de Cr\$10,00, mas era vendida por $\mathrm{Cr} \$ 3,00$.
} 
pretensões sofisticadas e de amplo alcance ao público leitor”.

A Cultura Política: uma revista de estudos brasileiros, não era uma revista literária, como se pode pensar apressadamente a partir do que sugerem o título e subtítulo. Na verdade, ela nascia como a voz oficial da proposta estado-novista, propunha-se a ser um órgão informativo de amplo espectro, ou seja, "combinar tal tarefa com a preocupação explícita de formar consciências em apoio aos ideais do estado Novo, que eram, em sua ótica, os ideais da nacionalidade brasileira" (GOMES, 1996, p. 127-128). Assim, a revista problematizava assuntos diversos. Ia da Política Militar e Defesa Nacional, passava por Problemas Internacionais, Administração, Economia até desaguar nas Artes e Ciências Humanas, a exemplo das seções de Música, Literatura, Lingüística, Filosofia e História. Dividida em seções, cada uma vinha sempre precedida de uma "nota introdutória", onde se esclarecia o tema que seria desenvolvido, sendo fornecida também uma bibliografia do autor ou autores que assinavam as matérias. É oportuno lembrar que a divisão das seções visava abarcar as diversas dimensões de uma política cultural que se queria sofisticada e de grande abrangência em termos de público leitor.

\footnotetext{
Cada seção, entretanto, vinha precedida de uma apresentação, onde se mostrava ser o progresso das artes, da ciência, da literatura uma decorrência das condições favoráveis advindas com o novo regime. O descompromisso de alguns articulistas era assim diluído no contexto da revista. Publicar na revista oficial, editada pelo DIP, era uma forma de participar da legitimação do novo regime. É exatamente essa capacidade de atrair para seu campo mesmo os opositores que merece destaque no empreendimento cultural programado e dirigido por Almir de Andrade (OLIVEIRA, 1982, p. 33).
}

A proposta da revista, segundo Velloso (1982), residia não apenas em propagandear o regime, mas, sobretudo, centrava-se na "produção do discurso". Ou ainda, nas palavras da autora,

\footnotetext{
A Cultura Política, conforme enuncia o seu subtítulo, configura-se uma revista de "estudos brasileiros", cuja proposta é a de "definir" e "esclarecer" o rumo das transformações sociais e políticas do país. As realizações do governo nos mais diversos setores - política, economia, técnica, arte, letras, ciências - são registradas (VELLOSO, 1982, p. 75).
}

O objetivo da Cultura Política não era modesto; ao contrário visava ao faustuoso: tinha distribuição mensal e seu tamanho variava, entre 250 a 300 páginas, o formato de 13,50 x 18,50 cm (a exceção são os últimos três números que apresentam o formato de 16 x 22,50 cm e cento e poucas páginas). Grandioso também era o número de colaboradores: em sua trigésima edição, em julho de 1943, 261 diferentes colaboradores já tinham passado por ela, e nas suas últimas edições, mais de 300. O número abundante de colaboradores poderia ainda 
ser maior. Afinal muitos outros, dela gostariam de colaborar. Isso se deve, em parte, pela contribuição paga pelo Estado; normalmente os colaboradores recebiam, sem atraso, o dobro do que pagavam as demais publicações que circulavam no mesmo período ${ }^{6}$.

Em seu primeiro número ${ }^{7}$ a revista expõe os objetivos gerais a que ela se destinava: definir e esclarecer o rumo das transformações sociais e políticas do país, sem obnubilar as realizações governamentais na política, economia, técnica, artes, letras e ciências. Acrescentemos então que, além desses propósitos, a revista tencionava promover e divulgar a política cultural que caracterizava o novo regime, principalmente na seção "Brasil social, intelectual e artístico". Nessa seção, e em suas diversas subseções, colaboram tanto os grandes intelectuais/ideólogos do Estado Novo, como também contribuem outros intelectuais, ocupantes ou não de cargos da máquina pública, sem compromisso explícito com a ideologia estado-novista. São na verdade "especialistas" em determinados assuntos e regiões convidados a cooperar em determinada subseção, seja de forma assídua ou apenas uma colaboração bissexta. Um exemplo dessas subseções está o "Quadros e costumes regionais", antes subdividido em partes dedicadas às regiões Norte (Raimundo Pinheiro), Nordeste (Graciliano Ramos) e Centro-Sul, (Marques Rabelo).

Cultura Política era dividida em seções (Problemas políticos e sociais, O pensamento político do chefe do governo (sob a responsabilidade de Azevedo Amaral e a ele se agregaria Rosário Fusco), A estrutura jurídico-política do Brasil, Textos e documentos históricos, A atividade governamental, Brasil social, intelectual e artístico. Cada seção oferecia ao leitor uma nota introdutória na qual objetivos e princípios norteadores eram justificados, além de apresentar os dados biobliográficos dos colaboradores. Velloso nos diz que:

\begin{abstract}
A preocupação em delimitar e/ou elucidar os objetivos, fundamentar os princípios de análise e precisar as fontes evidencia um alto grau de organização e eficiência no manejo da informação que, poderíamos mesmo dizer, é surpreendente no período. Estas características da Cultura Política permitem configurar a eficácia do projeto ideológico estado-novista e o seu elevado grau de elaboração na montagem da estratégia discursiva. Dado o papel específico que desempenha no projeto ideológico
\end{abstract}

\footnotetext{
${ }^{6}$ Conforme entrevista de Almir de Andrade concedida à Lúcia Lippi Oliveira em 10/01/1981.

${ }^{7}$ A revista passou por duas fases. De março de 1941, quando é criada, a maio de 1942, apresenta uma estrutura fixa de seis seções. Em 1942, em função do contexto político de alinhamento do Brasil com os Estados Unidos da América e da posterior entrada do país na guerra contra o Eixo, ela passa por modificações. Em setembro de 1942 sem deixar de ser "um espelho do Brasil" ela passa a difundir uma "cultura militar", voltada para a "segurança da pátria" e destinada a garantir a "defesa nacional". Deixa de possuir um número fixo de seções (antes eram seis) e passa a receber uma acentuada colaboração de militares (que se traduz em seções como "Política internacional", "O Brasil na guerra" e "O Brasil no exterior") e de profissionais com formação técnica. Em agosto de 1943, um ano após a declaração de guerra, a revista lança um número extraordinário.
} 
estado-novista, a Cultura Política funciona como verdadeira central de informações. Assim, tudo o que se escreve sobre Vargas e sobre o Estado Novo é assiduamente registrado nas suas páginas, através da seção bibliográfica (VELLOSO, 1982, p. 75).

A Cultura Política empreendeu, através de seu diretor, Almir de Andrade, uma bem sucedida tarefa: congregar em um só espaço uma multiplicidade de vozes, nem sempre afinadas com o regime. Seus colaboradores eram distintos também em suas trajetórias políticas e formações ideológicas. Como exemplo dessa heterogeneidade, lembramo-nos de Cassiano Ricardo (que apoiou o regime pela palavra e ação), de Azevedo Amaral, Nelson Werneck Sodré, Jaime de Barros, José Maria Belo, Gilberto Freyre, Graciliano Ramos etc. Em editorial intitulado "Brasil social, intelectual e artístico" se pode ler que, a partir daquele momento, a revista congregava a variedade: "Elementos das mais diversas correntes literárias, artísticas e científicas se encontram aqui representados, pois esta revista não tem partidos e há de procurar sempre espelhar tudo o que é genuinamente brasileiro" (Cultura Política, número 1, março de 1941).

Esse esforço exitoso de reunir na revista intelectuais que diferentemente entendiam a constituição cultural e política do país e seus problemas, empreendido pelo professor Andrade, nos parece ter um propósito que não era eminentemente altruísta, mas que pôde ter sido pensado e planejado visando a uma finalidade específica: “[...] atribui(r) ao intelectual um papel predominante enquanto intérprete da vida nacional” (OLIVEIRA, 1982, p. 33) e também porque a publicação apresentava uma abundância de assuntos, de seções, principalmente na seção "Brasil social, intelectual e artístico", que abrigava múltiplas e muito diversificadas subseções.

Velloso (1982) ainda nos chama a atenção para o fato de a Cultura Política congregar os "grandes intelectuais" do regime (Francisco Campos, Azevedo Amaral, Almir de Andrade, Lourival Fontes) os quais eram responsáveis diretos pela criação de uma determinada concepção de mundo, informadora do discurso autoritário, cujas idiossincrasias servirão como paradigmas para os "intelectuais médios", que se prontificarão a difundi-lo para o conjunto da sociedade. Sustentam esse mesmo pensamento Garbuglio et al. que nos dizem:

No campo intelectual [...] o Estado Novo tratou de produzir condições materiais e ideológicas que permitissem a mais fácil cooptação do maior número possível de intelectuais para colaborarem em seus órgãos oficiais de imprensa. Isso implicava "teorizar" uma concepção de cultura e de política, o que ficou a cargo de alguns "intelectuais orgânicos" (pelo menos os que assim se comportaram), como Almir de Andrade, Azevedo Amaral, Francisco Campos, Gustavo Capanema, entre outros (GARBUGLIO et al., 1987, p. 66). 
Seguindo esse mesmo raciocínio está Gomes:

No caso da Cultura Política [...] há tanto a presença dos grandes intelectuais/ideólogos do Estado Novo, que atuam em seções específicas e fazem uma discussão programática e sofisticada dessa nova proposta política, quanto a presença de colaboradores "especializados" em determinados assuntos, que podiam ou não ocupar cargos na burocracia dos poderes Executivo e Judiciário (GOMES, 1996, p. 133).

Portanto, abrir espaço na revista aos multíplices pensadores não deve ser entendido apenas como um gesto de abnegação do regime Vargas, mas pode ser interpretado como a implementação de uma bem sucedida política cultural de aproximação entre os intelectuais e o Estado nacional. Em outros termos, uma forma do governo buscar aproximar os intelectuais do poder, através da cooptação e, dado esse passo, a administração federal pode vender a imagem de um regime tolerante com os "diferentes" e com diferentes pontos de vista. É bom ressaltarmos que o governo ambicionava ventilar uma imagem distorcida, na qual os intelectuais passariam a ser vistos como agentes de um processo de transformação nacional, os quais desejam a emancipação cultural do país. Como é uma imagem desvirtuada e falaciosa, não se pode culpar o governo apenas por projetá-la distorcidamente, pois os próprios intelectuais têm sua parcela de necessidade econômica, omissão ou conivência nesse processo.

Muitos deles, ao corresponderem às expectativas ditadas pelo interesse do poder e das classes dirigentes, aceitando participar do governo, ratificam o espectro distorcido lançada pela administração federal. Boa parte desses intelectuais podia servir ao governo sem servir, isto é, sem abrir mão de sua autonomia mental, visavam apenas o retorno financeiro; outros tantos, não apenas serviram ao governo, como também se venderam a ele; a história já nos demonstrou.

A revista Cultura Política funcionou não apenas como um espaço de publicação e patronato. O governo, além de arregimentar centenas de intelectuais para a revista, muitas vezes também os brindou com cargos no serviço público federal, neutralizando, dessa forma, o papel de oposição, de contestador da ordem vigente, de outsider, que sempre coube aos intelectuais nas sociedades modernas.

Convocar os intelectuais para se enfileirarem do lado do regime e abafar muitas vozes desarmônicas não foi tarefa desenvolvida apenas pelo diretor da revista. O próprio presidente Vargas se empenhou nesta empreitada. Em um trecho de seu discurso, também já colocado em destaque por Oliveira (1982), quando tomou posse na Academia Brasileira de Letras em 1943, revela sua visão interessada da necessária aproximação entre a política e os 
intelectuais da Academia Brasileira de Letras. Segundo o presidente, desde a fundação da $\mathrm{ABL}$, políticos e intelectuais andavam em caminhos de mão dupla sem jamais se interligar, isto é, a relação era pautada pelo:

\section{[...] desdém recíproco e mútua desconfiança. Os literatos reclamavam o isolamento, a torre de marfim [...]. Os homens de ação, dedicados às tarefas práticas, desacreditavam, por seu turno, nas possibilidades reais dos que sabiam pensar e dizer [...]. Só no terceiro decênio deste século operou-se a simbiose necessária entre homens de pensamento e de ação (Vargas, 1943, p. 718)}

Por esse trecho melhor se delineia o propósito do governo: atrair, recrutar para sua órbita os intelectuais, inclusive os ligados à literatura, tarefa que é executada tanto pelo professor Almir de Andrade, como por Azevedo Amaral, Rosário Fusco e o próprio presidente Vargas.

Ao analisarmos o fragmento do discurso do presidente Vargas, notamos que este revela traços de outros ideólogos do governo. Gomes (1996) ao estudar os editoriais produzidos por Rosário Fusco para a Cultura Política expõe que, assim como os editoriais da área trabalhista, em que se nota um pacto político "firmado" entre os trabalhadores/cidadãos e o presidente/regime/Estado que marcava o fim do "longo divórcio entre os trabalhadores brasileiros e o Estado", há também, nesses editoriais de Fusco, a implementação de uma política cultural que procura aproximar os intelectuais do Estado nacional.

A autora mostra ainda que o Estado reconhece seu papel de manter a ordem política e o crescimento econômico, mas em relação ao mundo da cultura, o papel do Estado é tutelar, isto é, se entre este e os intelectuais não havia um divórcio, havia ao menos uma tradição de "afastamento ostensivo e consciente" entre gerações políticas e intelectuais. As causas desse distanciamento "radicavam-se nos intelectuais, ciosos de sua inteligência e céticos em relação à política”. Exemplo dessa tradição de alheamento são José de Alencar e Machado de Assis. O primeiro preferia ser reconhecido como homem de letras, o segundo proclamava-se indiferente aos interesses políticos. Mas para o editorialista da Cultura Política, a causa maior desse distanciamento residia na falta de iniciativa, de apoio das elites da primeira República às obras dos intelectuais brasileiros. Havia ainda a incompreensão dessa elite em relação a função social do intelectual.

A aproximação entre intelectuais e o Estado só começaria a se modificar, segundo Fusco, com o advento do Estado Novo, regime que estava trabalhando de forma exemplar 
para promover essa aproximação, principalmente a partir da Primeira Guerra ${ }^{8}$ - momento em que os intelectuais "acordam" e desejam compreender seu país, isto é, conhecer nosso passado, nossa gente e pensar nosso futuro. É, como estamos vendo, segundo a ótica de um ideólogo do Estado Novo, com a Revolução de 1930 que o distanciamento entre Estado e intelectuais começa a desaparecer. O grande agente condutor dessa aproximação será o Ministério da Educação e Saúde, o qual "percebia a relação profunda entre "produtores intelectuais" e meio social e garantia condições para que toda a vida cultural girasse em torno dos problemas da nacionalidade e da busca de suas soluções" (GOMES, 1996, p. 138).

Assim, entendemos que o discurso de posse do presidente na ABL, bem como o estudo empreendido por Gomes (1996) demonstram que, muito menos que um discurso acusatório por parte do Estado Novo, há uma atitude mental, na qual se deseja selar um acordo. De um lado, o Estado reconhece a necessidade de aproximar os intelectuais (homens de letras) ao Estado. Reconhece sua liberdade, ampara-os na política, fomenta as realizações culturais e coloca à disposição cargos públicos. De outro, espera que os intelectuais não se neguem a colaborar com o regime e ocupem os espaços para os quais são convocados e ajam como - "intérpretes da brasilidade", de nacionalidade, construam uma história "nossa", ou seja, o marco valorativo da produção intelectual deve ser o de repensar o Brasil. A palavra de ordem deve ser a adequação entre política e espírito nacional, aproximar o vínculo entre criação literária e nação, traço que já tinha se iniciado com os modernistas nos anos 20 (através de viagens e congressos realizados pela vanguarda cultural do país) e que passa a ser também o projeto cultural do Estado Novo.

Esse projeto colocará na ordem do dia a vinculação do escritor à construção de uma identidade nacional. Essa proposta cultural só será possível se os intelectuais romperem com a dependência cultural e se afastarem da imaginação. Ou seja, há um veto à ficção, à imaginação e um chamamento à racionalização. O projeto literário estado-novista passava por uma ligação profunda, e muitas vezes documental, do escritor à terra, ao seu local de origem (regionalismo) e às tradições de sua região, recuperando o passado histórico e preservando-o do esquecimento. Esse projeto literário-nacionalista devia possuir referências geográficas, históricas e culturais. Daí porque a criação da subseção "Quadros e costumes regionais", que se organizava por região, como vimos, e repetimos aqui: Norte (Raimundo Ribeiro), Nordeste

\footnotetext{
${ }^{8}$ Segundo diversos pesquisadores os anos do Pós-Primeira Guerra Mundial é tido como um período de intenso nacionalismo militante, principalmente pelas formações de organizações a exemplo da Liga da Defesa Nacional, Liga Pró-Saneamento, Liga contra o Analfabetismo etc.
} 
(Graciliano Ramos) e Centro-Sul (Marques Rebelo), e Literatura, subdividida em "literatura de idéias, histórica, latino-americana e de ficção, para a qual escreviam intelectuais como Prudente de Moraes Neto (Pedro Dantas), Gilberto Freyre e Nelson Werneck Sodré. Oportuno, entretanto, adiantarmos o que nos diz Lima (2001) ao estudar a capitalização de Euclides da Cunha para o projeto literário estado-novista, uma vez que o estudo dele confirma nossas afirmações.

O dever do escritor no projeto literário do Estado Novo é o da fidelidade ao seu tempo e ao seu núcleo de origem, ou seja, literatura igual a nação, através da região. [...] a autenticidade de uma obra literária passaria, necessariamente, pelo critério espacial (a região) e temporal (a história). Assim é que, por exemplo Machado de Assis é um escritor severamente criticado e estigmatizado pelo regime estado-novista, uma vez que rechaçava esse modelo [...] Euclides da Cunha representará a consagração do mesmo [...] Será o caráter documental da obra de Euclides da Cunha o primeiro aspecto que viabilizará a capitalização desse escritor para o projeto literário estadonovista (LIMA, 2001, p.81).

Voltemos, uma vez mais, ao fragmento do discurso do presidente Vargas na ABL e percebamos que na fala dele, assim como nos discursos do diretor da revista Cultura Política, tido pelos estudiosos como o doutrinador do regime, e nos editoriais de Rosário Fusco, existe uma afinação de propósitos culturais. O que eles objetivam é arregimentar os intelectuais, os "intérpretes da brasilidade", chamá-los para o lado do governo e em troca, acenar com espaços de publicação e retorno financeiro.

Mas a aproximação do Estado Novo com os intelectuais não ficou apenas no espaço da revista. Além da Cultura Política e da ABL, o governo e os intelectuais estreitam relações nas livrarias. A José Olympio, por exemplo, foi um espaço de recrutamento, conforme nos dizem Garbuglio et al.:

[...] encontram-se a intelectualidade da época. Escritores, pintores, inúmeros ministros do Estado Novo, como Osvaldo Aranha, Gustavo Capanema, João Neves da Fontoura, Macedo Soares, Francisco Negrão de Lima e Otávio Tarqüínio de Souza. O ambiente da livraria parece propício - e ao mesmo tempo revelador, emblemático até - à aproximação que o Estado Novo promove coma intelectualidade. Há uma "democratização" das relações, muito facilitada pela presença de Gustavo Capanema no Ministério da Educação e Saúde, que tem Carlos Drummond de Andrade como seu chefe de gabinete e promove uma política sistemática de atração dos intelectuais (GARBUGLIO et al., 1987, p. 69 grifo nosso). ${ }^{9}$

\footnotetext{
${ }^{9}$ Há uma crônica de Graciliano Ramos em Linhas Tortas, intitulada A Livraria José Olympio, na qual o cronista revela o "ar de família" que reina nesses encontros. Transcrevemos um trecho iluminador: "Há um ar de família naquela gente. Otávio Tarquínio deixa de ser ministro e Amando Fontes deixa de ser funcionário graúdo. Vemos ali o repórter e víamos o candidato a presidente da república, porque José Américo aparecia algumas vezes. Lins do Rêgo é figura obrigatória. Marques Rabelo procura vítimas. Distribui veneno a presentes e ausentes. É uma galeria muito vasta, onde figuram críticos, sociólogos, ficcionistas, ensaístas, etc. A pintura está representada por Santa Rosa e Portinari. Dessa camaradagem, em que as fronteiras sociais desaparecem, misturam-se as artes, tudo se aproxima. Luís Jardim ganha diversos prêmios, abandona os pincéis e muda-se para o campo dos literatos. Gilberto Freyre, Almir de Andrade e Hermes Lima não têm aparência de professores e dificilmente se
} 
A confraria de tantos intelectuais de diversas colorações, em vinculações políticas e ideológicas díspares, tem também, acreditamos, outro propósito: o governo quer fazer crer seu caráter nacionalista e apartidário, como já afirmara Almir de Andrade em editorial. Mas esta é uma posição frágil e que se desmente. O DIP é um órgão de censura, de cortes, de violência contra a liberdade de expressão. O que nele se opera é uma relação de cooptação e os colaboradores, conscientes ou não, embaralham, ao invés de manter imparcial, a relação entre Cultura e Política. Almir de Andrade é quem nos revela que a relação entre cultura e política devia ser vista, a partir da revista, como indissociável:

Tudo o que um povo produz pela sua cultura representa suas aspirações e necessidades de vida; a cultura é esse mesmo povo vivendo, criando obras de arte e de pensamento, costumes e tradições, formas de convivência e hábitos sociais. Mas nada disso subsiste sem a garantia de uma organização capaz de manter a paz, de conciliar interesses, de harmonizar tendências, de ajustar as necessidades de cada um às exigências de todos. E essa organização - que defende, que sustenta, que permite o desenvolvimento de uma coletividade através de todos os seus elementos de cultura é a ordem política (Cultura Política, n. 1, março de 1941, p. 7).

Interessante nos parece também a relação entre os intelectuais que escreviam na revista, e a classe média para quem ela se destinava. Dizendo de outra forma, a revista, embora tenha em vista um largo espectro de leitores, não se direciona ao grande público. A complexidade dos temas problematizados pela revista, as particularidades técnicas e o grau elaborado do discurso, muitas vezes flertando o eruditismo, em que concepções filosóficas acerca da natureza do Estado e da nação, do lugar ocupado pelo sujeito/indivíduo na política etc., são levantados, refletem a origem de seus colaboradores e a quem ela objetiva alcançar: a elite intelectual do período ${ }^{10}$.

Isso nos leva a afirmar que a revista se dirigia a um grupo de leitores restrito, formador de opinião, os chamados "intelectuais médios”, com grau de instrução bem acima da média brasileira (o índice de analfabetismo neste momento girava em torno de $56 \%$ ) e um interesse grande pelos mais diversos assuntos, afinal, como já notamos, a revista discutia uma diversidade de problemas nacionais. Quem escreve para a revista, escreve mirando a si mesmo, tal qual Narciso. Isto é, a publicação oficial visava alcançar os seus próprios pares: a

poderia saber que Peregrino Júnior, Gastão Cruls e Rui Coutinho são médicos. Murilo Mendes é apenas poeta, mesmo quando escreve política; Lúcio Cardoso é apenas romancista, mesmo quando faz artigos. Há ali crentes e descrentes, homens de todos os partidos, em carne e osso ou impressos nos volumes que se arrumam nas mesas, muitos à esquerda, vários à direita, alguns no centro. O editor é liberal. Se tem simpatia para qualquer extremidade, oculta-a" (L. t. p. 121).

${ }^{10} \mathrm{O}$ regime Vargas consegue atingir um público maior e mais diversificado com a montagem do diário carioca $A$ Manhã, que começou a circular em agosto de 1941, como porta-voz do Estado Novo. Além de uma explícita intenção doutrinária, possuía também uma proposta cultural estado-novista via caderno Autores e Livros. A esse respeito consultar Gomes (1996). 
elite intelectual escrevia para a média elite cultural do país. Nas palavras de Garbuglio et al. (1987, p. 68), ela é "a revista da elite e para a elite intelectual, sob a tutela do DIP”. Nos termos de Velloso (1982),

Cultura Política congrega os "grandes intelectuais", responsáveis pela criação de uma determinada concepção de mundo, informadora do discurso autoritário. A importância desses intelectuais é notória no conjunto do projeto ideológico estadonovista, dado que os seus discursos servirão como paradigma para toda uma camada de "intelectuais médios", que se prontificarão a difundi-lo para o conjunto da sociedade (VELLOSO, 1982, p. 81).

Assim, podemos afirmar que a revista Cultura Política desempenhou um papel capital, decisivo como um dos mecanismos difusores da imagem do Estado Novo. Seu diretor, e por trás dele, o presidente Getúlio, souberam habilmente manejar a capacidade de angariar adesões, produzir e fazer circular discursos que justificassem o novo regime, além de conciliar um ecletismo de idéias provenientes dos seus mais diversos colaboradores. Dentre esses colaboradores mais conspícuos estava Graciliano Ramos.

\section{As crônicas da revista Cultura Política: meio de falar pelo avesso}

Em Vivente das Alagoas constam vinte e duas crônicas. Nenhuma traz referência do local onde foram publicadas. Duas outras foram inseridas em Linhas Tortas e também não trazem especificações de data e local de publicação. Os títulos das crônicas foram atribuídos postumamente. Outra crônica - Uma visita inconveniente - publicada na seção "Quadros e costumes regionais" (Cultura Política, ano II, n. 22, Rio de Janeiro, dez. 1942, p. 154-155) não foi inserida em nenhum dos livros. O total de textos soma vinte e cinco crônicas, geralmente com duas páginas.

As crônicas publicadas por Graciliano Ramos, incluídas nos "Quadros e costumes do Nordeste" ou "Quadros e costumes regionais" ou "Quadros regionais" foram estudadas, em seu conjunto, por Garbuglio et al (1987), os quais se referem ao escritor alagoano e ao conjunto das crônicas, dizendo-nos que:

Graciliano escreve pois, na revista da elite e para a elite intelectual, sob a tutela do DIP, onde a ambigüidade e mesmo a oposição eram toleradas, o que permitia ao escritor, ao mesmo tempo, manter as ilusões de sua independência pessoal e receber vantajosa remuneração por seus textos, de vez que aquela revista era a que melhor pagava (e em dia...) os seus colaboradores. Tudo no interior do mesmo projeto ideológico, evidentemente. Por isso é que os textos de Graciliano preenchem seções da revista previamente fixadas por seus responsáveis, homens do DIP, os "intelectuais orgânicos". E os temas, em geral, enquadram-se no circuito de "descoberta e produção" do homem novo pretendido pelo Estado Novo, onde o aparelho de Estado 
aparecia como capaz de "traduzir a vocação popular", através do estímulo ao conhecimento da realidade brasileira, em seus aspectos de "observação sociológica e investigação da psicologia nacional”. O que implicava a descoberta e valorização do regional e do passado, pois, conhecidos estes, mais facilitada estaria a tarefa que o Estado/governo/povo se "propunham": realizar no presente aquilo de melhor que os obstáculos externos tinham impedido o passado realizar (GARBUGLIO et al. 1987, p 68, grifo nosso).

No fragmento em destaque, o autor observa com bastante acuidade o que o Estado Novo pretendia com seu projeto cultural: o tema central do Estado autoritário, via revista, é desenvolver, através dos intelectuais convidados para colaborarem nela, uma identidade nacional, ou nos termos do autor, uma "realidade brasileira". E o conhecimento dessa realidade passava pela "descoberta do homem novo", capaz de se comunicar com as tradições regionais, ou seja, os intelectuais, e dentre esses Graciliano, deveriam ser especialistas em captar e expressar a "realidade" brasileira e valorizar, em seus escritos, tipos humanos regionais e o passado.

Conforme sugerem as palavras de Garbuglio et al. (1987) a busca pela singularidade, por uma identidade nacional, não é um objetivo novo, desse Estado autoritário, mas é uma retomada de um mesmo tema que já ocupava a pena dos intelectuais brasileiros desde o Romantismo até as vanguardas dos anos 20. Confirmam nosso posicionamento Lima (2001) citado por Melo (2001) que nos lembra que:

A discussão do tema identidade nacional, feita pelo Estado Novo, realiza-se como retomada dos temas que vinham ocupando os intelectuais brasileiros desde os primeiros momentos em que o Brasil pretendeu inserir-se no rol das nações civilizadas. [...] Até os anos 20 era inconteste, nessa interpretação, a visão positivista de inspiração comteana. Já aqui surgiam os dois brasis, aquela moderna civilização litorânea e o sertão distanciado espacial e temporalmente desta. [...] Tratava-se de compreender os padrões tradicionais de nossa organização social, política e econômica, confluindo, nesse sentido, literatos e cientistas. A discussão pendia entre os pólos do moderno e do tradicional, do progresso e do atraso, bem como do litoral e do sertão. [...] O tema da identidade nacional, que a modernidade impunha, lança o olhar desses homens do início do século XX para um Brasil ainda incipientemente explorado, seja pela literatura dos românticos e naturalistas, seja pelas descrições dos viajantes dos séculos XVIII e XIX. A evocação de uma cultura autêntica encontrada nesse Brasil e o projeto modernizador defrontavam-se. Nos anos 30 novas respostas surgirão para a compreensão das ambigüidades. O projeto modernizador, com a Revolução de 30, acentua-se como uma verdadeira renovação do país. [...] O paradoxo dessa modernidade, a "realidade brasileira" [...] era o tema do momento entre sociólogos, literatos e historiadores [...] Datam deste período as primeiras obras de orientação marxista, entrando em voga conceitos como de proletariado, burguesia, etc. O debate, sobretudo em seus aspectos críticos, sofreu nos anos seguintes, com o Estado Novo, restrições de todo tipo. [...] O papel dos intelectuais é [...] redefinido. Tratava-se, a partir de então, de realizar uma acomodação e, se possível, uma cooptação. [...] A proposta da revista [...] procurava sublinhar o presente e seu aspecto inovador. Apoiando-se numa perspectiva de recuperação do passado, de exaltação da história nacional, a nova ordem, através de seu chefe supremo, restaurava a brasilidade perdida no projeto liberal. O presente, em seu novo projeto, era a concretização da identidade nacional. O novo Estado era agora fundado na 
alma nacional, na sua história e tradições (MELO, 2001, p. 66-67, grifo nosso).

Cotejadas as citações, percebemos que elas convergem para um ponto comum: a política cultural estado-novista deseja que os intérpretes da brasilidade - os escritores redescubram as raízes nacionais, isto é, recuperem e valorizem a língua, os costumes, as tradições, a cultura popular, em síntese, a memória de um Brasil ainda desconhecido e dêem resposta à pergunta - que país é este?

Os textos de Graciliano Ramos para a Cultura Política parecem encaminhar-se para a observação de tipos sertanejos, seus costumes, principalmente porque estas descrições estão contidas nos quadros regionais.

Antelo (1984), também estudou parcialmente as crônicas publicadas na Cultura Política. Para este estudioso, elas se ordenam em torno de duas funções principais:

\begin{abstract}
De um lado, há os que ensaiam o memorialismo, mais ou menos na linha do que seriam Infância e Memórias do Cárcere; de outro a viagem, a descrição de outros costumes. Em ambos os casos, desponta o olhar adulto do escritor já ambientado no Rio. Poder-se-iam distinguir, ainda, as isotopias fundamentais dessas crônicas. A meu ver, a principal, talvez, seja a do deslocamento, concretizando, em diversos contextos, a tensão entre norma e desvio (ANTELO, 1984, p. 27-28).
\end{abstract}

Ao longo de seu estudo, Antelo procura sublinhar não os aspectos da busca de uma "identidade nacional" e a "recuperação do passado", embora confirme que há as "descrições de costumes". Todavia, para o crítico, maior que esses motes, estão a norma (o mandonismo masculino, a aceitação das leis da sociedade, o poder censurador da igreja, a instituição dos proprietários, o casamento etc.), o que se afasta do convencional, além do memorialismo. Outro ponto destacado pelo professor Antelo é a posição de narrador assumida por Graciliano Ramos nessas crônicas:

[...] a posição do narrador [...] simpatiza com os fracos, mas pertence ao mundo dos proprietários. Daí uma posição intersticial, ambígua, instável, que se constrói apelando alternativamente, a traços de ambos os grupos [...] Nessa rígida dialética entre o fora e o dentro, o forte e o fraco, Graciliano tende ao ponto de vista do forte e do fora. Narrador urbano, já distanciado desses viventes ora evocados, sua mediação se estabelece a partir de uma posição - no caso, claríssima - no aparelho do Estado. O romancista de prestígio "dentro" e entre os fracos é pago para fixar quadros e costumes do Nordeste, ou seja, congelar o mutável no marco de uma visão autoritária e exterior (ANTELO, 1984, p 33-34).

Outro ponto que mereceu destaque nas análises empreendidas pelo referido autor foram as vinculações entre os personagens que aparecem nas crônicas e a figura do próprio escritor (“o ajudante da farmácia é um claro desdobramento do autor [...] nada custa identificar o velho Graciliano na figura do cantador [Inácio da Catingueira] [...] O Dr. Pelado é uma curiosa projeção do autor"). 
As aproximações do homem Graciliano com suas crias, elaboradas pelo professor Antelo, não diminuíram seu trabalho, mas o enfraqueceram na medida em que ele força uma aproximação entre narrador e autor. Em uma crônica, assinada com o pseudônimo dea J. Calisto, que já alertava a um suposto leitor de sua crônica para esse perigo (confundir o cronista com o narrador): "Eu não sou ele. Logo, ele não pode ser eu. [...] Somos duas pessoas distintas e duas pessoas verdadeiras, sem mistério nenhum" (RAMOS, 1980, p. 79). Devido à essa justaposição, Raúl Antelo empreendeu também, em muitos momentos de seu estudo, uma análise psicanalítica das crônicas. Nessas apreciações, fatos, narrações, personagens, metáforas e símbolos foram estudados e serviram de matéria para explicações a partir de bases freudianas. Vejamos alguns exemplos que ratificam nossa afirmação:

[...] Nessa busca transparece, não raro, uma certa erotização da morte (o pelado escolhe o sertão: cascalho e espinho) quase milagrosa (leite das pedras) que é a contrafigura ideológica de uma restrição da vida: a mulher fálica (ANTELO, 1984, p. 47).

[...] podemos pensar que Graciliano esboça o arquétipo do ancião sábio, ora na figura do antepassado, ora na do funcionário independente ou do sociólogo estrangeiro. Em todas estas personagens masculinas, a imperfeição da barroca flui à natureza calejada do físico das vestes (nódoas, negrumes, roupas surradas, roídas), idéia que se contamina com a noção de sujo (barba, caspa) [...] (idem, p. 49).

Há, não se pode negar, nas crônicas escritas para a Cultura Política rememorações, descrições de tipos e costumes e, possivelmente, experiências vivenciadas pelo homem Graciliano. Além disso, as crônicas tematizam o Nordeste e sua gente. O cenário será sempre o sertão nordestino, assim como é esse mesmo cenário o pano de fundo para a maioria dos seus contos e romances, antes e depois da prisão. Graciliano não se desliga deles, mas é preciso relembrar, a partir de um ensinamento de um mestre da ficção que "a raiz de todas as histórias está na experiência de quem as inventa; o que se viveu é a fonte que irriga a ficção" (VARGAS LLOSA, 2009, p. 19).

Como Antelo, notamos que o narrador desses textos ao construí-los, volta seu olhar para um Nordeste pretérito (muito embora o que ele descrevia ou comentava ainda podia ser o presente da região) para a "recuperação do passado". Nesse aspecto, adiantamos, o escritor atende, pelo menos nos temas e, na linha espacial, a proposta cultural da Cultura Política. Isto é, a referida revista propunha, no quadro "costumes regionais" a valorização das expressões geográficas.

Graciliano, portanto, cria um narrador "rural", que procura recuperar o dia-a-dia do povo no campo ou nas pequenas cidades sertanejas. Flagra seus hábitos, abre as portas de suas 
casas, descortina para o leitor as festas e tradições dessa gente. Por essa via, esse narrador se contrapõe a três cronistas famosos (João do Rio, Olavo Bilac e Lima Barreto), cronistas citadinos que narravam o diário urbano. Esse narrador, entretanto, não se contradiz aos primeiros narradores criados por Graciliano Ramos; lembremos que R. O. e J. Calisto privilegiavam, sem que lhe impusessem, temáticas nordestinas. $\mathrm{O}$ narrador ficcional Graciliano Ramos que escrevia para seminários e jornais de grande circulação, abordava aspectos da literatura.

Mas há uma diferença entre o narrador da Cultura Política e os demais. Para aqueles, não havia um espaço pré-determinado - havia o espaço preestabelecido no jornal, mas não em uma seção específica - como é o caso da revista - nem havia assuntos previamente estabelecidos. A escolha dos temas era livre, ao gosto dos narradores. As crônicas do início de carreira tanto podiam problematizar o cotidiano das cidades e seus personagens, como também refletir fatos sociais e políticos. Aliás, na abordagem desses aspectos verificamos, em nossas apreciações, uma crítica aberta aos contra-sensos brasileiros. Podemos notar também que, tanto J. Calisto quanto R. O. eram cronistas no sentido mais estreito do termo, isto é, flagraram o habitual das cidades, dos homens e mulheres que habitavam a geografia fluminense ou alagoana.

Portanto, o narrador da Cultura Política se distancia do tempo presente, ou seja, narra olhando para o passado, como se o congelasse. Não se encontram referências explícitas que atem o passado ao presente (cabe ao leitor mais atento fazer essas ligações entre esses tempos distintos). As horas que marcam as crônicas do DIP foram acertadas por um relógio cujos ponteiros estão invertidos; o compasso é de um ritmo diverso daquele do cotidiano. Esse narrador se nutre quase exclusivamente de temas memorialistas, fatos "vividos ou observados alhures". É a memória que alimenta os temas que serão comentados por ele. Temas homogêneos - sempre aspectos e experiências nordestinas - e essa temática monocórdica, ficcionalizada, se torna mais atraente e mais verossímil. A favor desse narrador está o fato de que esse é o método ficcional de Graciliano compor: embaralhar, misturar os tempos e ficcionalizar o vivido. Mas fato é que o narrador da Cultura Política é "forçado" a contrariar os ponteiros do tempo, e empreende um resgate da memória (semelhante ao memorialismo de Infância), uma recuperação do passado (regional) e ficcionaliza esses eventos. A discussão que seus textos irão provocar é uma reflexão sobre o "tradicional (regional)", o "atraso (litoral X sertão)" e de uma cultura, um modus vivendi ainda incipientemente explorado ou cultivado 
de forma exótica. É verdade que ao percorrer temas como o carnaval antigo, o casamento sertanejo, o provincianismo dos costumes, a frustração dos pequenos intelectuais, o faz sem afirmar uma glória afirmativa de uma identidade pretendida pelo Estado Novo. A sua visão é crítica, embora não seja aberta como as crônicas de R. O. e J. Calisto, mas a ironia paira em cada detalhe, em cada descrição. Recusa-se a romantizar o sertanejo e denuncia o atraso e a pobreza que assolavam homens e mulheres que viviam, muitas vezes, como bichos.

"Encarcerado", pelo quadro da revista, a um determinado tema e região, seguindo os preceitos ideológicos da revista que pretendia valorizar a observação sociológica e a investigação da psicologia nacional, além da (re)descoberta e valorização do regional e do passado, o narrador é, de certa forma, obrigado a olvidar os acontecimentos que estavam na ordem do dia, esquecer a contemporaneidade dos fatos. Por isso esse narrador constrói seus textos deitando o olhar para o passado, os aspectos sociais urbanos do presente se esvaecem, e em seu lugar aparecem as tradições rurais nordestinas.

O narrador desses quadros, agindo assim, atende, mesmo que não o perceba claramente, aos ideais culturais ideológicos da Cultura política: priorizar a nossa brasilidade, isto é, a redescoberta do Brasil através da recuperação das raízes nacionais das nossas tradições rurais, nordestinas. Mas, é preciso advogar a seu favor que, embora ele valorize essa brasilidade, coloque em destaque a região, tradições e costumes, além de valorizar o dialeto desses sertanejos, o narrador não fará um elogio ao homem forte, nem utilizará um tom ufanista, desejados pelo projeto nacionalista do Estado Novo. Ao contrário, ele é capitalizado ao projeto cultural estado-novista, porém, dele se distancia porque suas descrições terão as marcas cruas da realidade e as tintas usadas nessas páginas dispensam os retoques e os adornos. Assim, verificaremos que o projeto "modernizador e renovador" do Estado Novo encontrará nesse cronista não um aliado, mas um crítico irônico, que se servirá de instrumentos expressivos e contundentes para se opor a esse projeto. Servem-nos como exemplos de armas utilizadas o tom acrimonioso, o silêncio e as imagens evocadas.

O narrador da Cultura desloca para o passado distante o seu olhar. Alimenta sua pena a partir de temas vividos pelo cronista e os reelabora ficcionalmente. São exemplos dessa técnica quadros como "Carnaval", "Ciríaco" e "O Moço da Farmácia". As experiências que ficaram registradas na memória do cronista servirão de leitmotiv para compor quadros como “D. Maria Amália" e "Bagunça", entre outros. Desenterrando reminiscências e fatos vividos há muito tempo pelo cronista (e elevando-as ao plano da ficção) ao mesmo tempo em que se 
vale da sua imaginação, o cronista da Cultura Política nos demonstra claramente o veto “imposto" a ele, ou seja, o escritor não pode se servir de experiências e memórias, vividas ou observadas recentemente, isto é, as marcas da prisão, do porão do navio que o levou ao Rio, nem as celas das cadeias que o encarceraram, para não envilecer, afrontar o governo, nem fugir à temática do quadro da revista. Como já notaram Garbuglio et al. (1987) pode haver ambigüidade, e acrescentamos nós, ironia viperina e humor sarcástico, mas nesses quadros não é permitida uma oposição aberta ao regime, nem tampouco uma independência pessoal.

Se, de um lado, há para o escritor a oferta de um espaço bem remunerado de publicação, de contato com o seu público, de outro, há uma suspensão de temas memorialistas e ficcionais que possam revelar as marcas da arbitrariedade sofridas pelo escritor e de outros temas que possam expor explicitamente a realidade política do país naquele momento, logo pode-se criticar o passado político, não o presente, pois o leitor é que deve construir essa ligação. Por isso, acreditamos que, se sob o signo da lembrança do passado, é possível uma afirmação da subjetividade, essa subjetividade e esse passado não podem se afirmar no passado recente.

A recriação subjetiva do presente é negada, embora possa ser driblada pelo narrador. Entretanto, o "permitido" é recuperar subjetivamente o passado, relembrar aspectos regionalistas, paisagens alagoanas e pernambucanas. O narrador da Cultura Política explora, e bem, essa recriação, muito embora não empreenda um elogio, uma louvação a esses fatos ou a essa região. Ao contrário, o narrador subverterá o discurso panegírico desejado pelo Estado Novo, utilizará a ironia como procedimento literário para desvelar as enfermidades ainda vivas e recorrentes daquela região.

Graciliano, ao participar do projeto cultural do Estado Novo, entretanto, não aprovou a política cultural desejada pela revista. Mas para sobreviver, aceitou cargos, trabalhou na revista do DIP, revisou textos, se "acanalhou", "contaminou os dedos" porque necessitava trabalhar, uma vez que "outros espíritos miúdos dependiam de nós e era preciso calçá-los, vesti-los, alimentá-los [...] (RAMOS, 1969, p. 4).

O narrador da Cultura Política revela-nos também que, além de servir de fatos vividos e reelaborá-los ficcionalmente, dando-lhes autonomia, ele procura exercer, não se pode negar, o papel de intelectual, de escritor que se comunica com o público leitor e toma determinados posicionamentos, embora não se posicione de forma clara e crítica como fizera em outros suplementos literários. É preciso trabalhar e manter o ajustamento de conduta para 
com a publicação. O narrador das crônicas da Cultura Política é consciente, sabe de onde fala, sobre o que deve falar e da importância de sua presença naquele espaço para a revista. Ele, como também dissemos, a legitimiza. A forma que tem para burlar as imposições e a situação incômoda é o uso da palavra bem talhada, do discurso interlinear. Ele procura aproveitar as brechas oferecidas pela literatura, pela ficção, para mostrar um sertão e um sertanejo que se afastam daquela visão de brasilidade romântica. Mas acreditamos que ele também tem a consciência de sua participação contraditória, isto é, ataca, denuncia, mas permanece colaborando. Não comunga com o projeto cultural, mas dele não se afasta.

Ao colaborar na Cultura Política, o narrador prossegue acordando reminiscências vividas ou testemunhadas e recriando-as subjetivamente. Mas ao invés de romantizar o sertão, cantar seus heróis, ele insiste em dar voz e vez aos anti-heróis. No lugar da "nacionalidade ufanista", na glamorização do sertanejo forte, o cronista abre veredas para que outras imagens apareçam e o leitor entre em contato com uma região atrasada, comandada por políticos que visavam o benefício a exemplos das crônicas Teatro I e D. Maria Amália nas quais denuncia a manutenção de valores patriarcais. Em outros textos, verif o narrador recupera a verdadeira realidade nacional, ao eleger não as estátuas de bronze representativas de heróis nacionais, a não sagrar personalidades ilustres nordestinas para lhes prestar homenagens, mas opta em desenterrar homens e mulheres comuns, os anônimos, os deserdados do processo civilizatório.

\section{Conclusão}

O cronista da revista do DIP precisa do trabalho e é bem remunerado, entretanto, não pode escrever contra e abertamente contra quem lhe remunera. A saída é escrever por alusão, por silêncios prenhes de significados. Cabe ao leitor o papel de arqueólogo, ou seja, reconstruir a história através de pequenas pistas, fragmentos lançados pelo narrador. Cuidadoso, esse narrador ausenta fatos tidos como reais que o possam colocar em perigo. Em outros termos, o narrador opera nos mesmos níveis propostos por Iser (apud COSTA LIMA, 1983), isto é, um processo no qual a seleção, a combinação e o desvelamento ficcional concorrem para "os atos de fingir":

[...] O texto ficcional contém muitos fragmentos identificáveis da realidade, que, através da seleção, são retirados tanto do contexto sócio-cultural, quanto da literatura prévias ao texto. Assim retorna ao texto ficcional uma realidade de todo reconhecível, posta agora, entretanto sob o signo do fingimento. Por conseguinte, este mundo é posto entre parênteses, para que se entenda que o mundo representado não é o mundo dado, mas que deve ser apenas entendido como se fosse. Assim se revela uma 
consequiência importante do desnudamento da ficção. Pelo reconhecimento do fingir, todo o mundo organizado no texto literário se transforma em um como se. [...] Assim, na verdade, a realidade se repete no texto ficcional, mas essa repetitividade é superada por estar posta entre parênteses [...] o modo característico da ficção é a transgressão de limites [...] (Apud COSTA LIMA, 1983, p. 397-400).

A busca por uma identidade conflitiva em um espaço restritivo, a alfinetada no regime, a ausência que se presencia são recorrentes ao longo das crônicas. O leitor do texto, assim como o narrador, sabem que o país, e não apenas o Nordeste, está infestado por "malandros" que desejam esfolar os "otários": “[...] O malandro veio ao mundo para esfolar, o otário deve ser esfolado. [...] - Quem é do chão não se trepa. Quem nasceu para vintém não chega a tostão" (V. A. p. 100).

A participação de Graciliano Ramos como cronista da Cultura Política fez com que muitos "críticos", apressadamente, enxergassem um alinhamento político-ideológico ao Estado Novo, até mesmo sugestionaram uma cooptação. Mas as insinuações se basearam na assinatura, no nome emprestado à publicação e não na análise profunda do conteúdo do texto escrito. Para essa parcela de desconfiados, Graciliano Ramos punha sua pena a serviço de um governo reacionário que há pouco o havia encarcerado. Esses mesmos estudiosos trouxeram à baila apenas a relação do intelectual com o poder, sua associação a uma revista financiada por um órgão de censura do regime de exceção, o DIP, e não foram capazes de notar que o autor alagoano não foi um militante político, mas um escritor cuja obra revela um projeto social emancipador e para quem o ofício da escrita constituiu não só um elemento de sobrevivência, mas de comunicação com o público, veleidade de todo escritor.

Julgaram utópico e idealizante acreditar que um escritor, por ser intelectual, tivesse que se isolar, se posicionar acima ou à parte das contradições dos regimes centrados no capital e no autoritarismo e também não perceberam a contradição, inerente a todo ser humano. Como vimos, a precária situação financeira do escritor foi determinante na aceitação da oferta de trabalho na revista, e o próprio romancista tinha consciência que enfrentaria insinuações que poderiam comprometer seu nome. O diálogo com o filho, Ricardo Ramos, e as conversas com amigos próximos atestam seu receio de macular política e ideologicamente seu nome. Mas, maior que o receio, estava a penúria econômica, por isso, aceitou a oferta e permaneceu quatro anos colaborando na publicação estado-novista, afinal, como afirmou, mais tarde em

\section{Memórias do Cárcere:}

[...] outros espíritos miúdos dependiam de nós, era preciso calçá-los, vesti-los, 
alimentá-los, mandá-los ouvir cantigas e decorar feitos patrióticos, abandonamos as tarefas de longo prazo, caímos na labuta diária, contando linhas, fabricamos artigos, sapecamos traduções, consertamos engulhando produtos alheios. De alguma forma nos acanalhamos (RAMOS, 1969, p. 4).

Nas crônicas da Cultura Política pudemos perceber que de dentro desse Aparelho Ideológico do Estado, os textos produzidos por esse narrador não revelam, voluntariamente, alinhamento ao projeto cultural, ideológico da revista e por extensão do Estado Novo. No entanto, seus textos foram utilizados de forma ideológica pela revista, ou seja, "para além da escritura do próprio autor ou de suas posições ideológicas pessoais [...] o uso que a revista estado-novista faz dos textos e o contexto em que ela os coloca estabelecem a conexão com o projeto do regime. Uma literatura de tradição documental" (GOMES, 1996, p. 176). É o que nos diz também, em outro contexto, Magalhães (2001, p. 30) ao nos alertar que "o uso ideológico/prático de qualquer criação humana não está sob o controle do criador, após a inserção no meio social".

É verdade que o narrador das crônicas da Cultura Política dispunha de um espaço mínimo na revista para se movimentar e nesse estreito limite procurou se "mexer", mas seus passos não se traduziram em atos revolucionários, em textos panfletários. Como sempre, ele busca na palavra escrita e nos estratagemas do tecido literário seu meio de protesto, mecanismo de movimento que contrarie o projeto literário nacionalista do regime de exceção e não se "acanalhar" além da conta. Lendo e relendo os escritos publicados na revista do DIP pudemos comprovar sua dissidência do projeto cultural do Estado Novo. Projeto que, como vimos, no plano literário-nacionalista, impunha a feitura de textos que privilegiassem referências geográficas, históricas e culturais, além de recuperar o passado. O cronista, em seus textos, atendeu a esses aspectos, mas também o contrariou ao não retratar o regional pitoresco, negando-se a romantizar a região e os matutos sertanejos e seus modos, costumes e tradições foram mostrados sem entusiasmo, saudosismo ou modelos de preservação. Foi pela contraversão àquelas normas que descortinou uma região subdesenvolvida, desvelou as condições miseráveis de vida no Nordeste, desnudou a indigência, o atraso, o abandono de homens e mulheres que viviam como bichos. Homens e mulheres submetidos, historicamente, à brutalidade da exploração agrária, ao descaso político, apartados da marcha civilizatória que vinha se impondo nos grandes centros urbanos, no litoral e que se mantinha longe do sertão. Revelou ainda como, por trás de determinados costumes e tradições se preservam o machismo, o preconceito, a malandragem, a debilidade cultural (analfabetismo, falta de meio de difusão de livros, etc.) e a anarquia financeira com o dinheiro público de determinados 
políticos.

O cronista, ao apresentar esses quadros, soube contrastar o cinza da região com as cores fortes da ironia. O narrador da Cultura Política utilizou, como apontamos, os "dados escondidos/escamoteados", a "narração por omissão", os silêncios significativos, exigindo portanto, do leitor e do apreciador, um aguçamento para a leitura dos textos, uma postura mais ativa na construção de sentido.

O narrador da Cultura Política corroeu ainda o projeto literário, cultural e ideológico da revista ao não balizar seus textos pelos retoques, isto é, a chamada "realidade brasileira", a "identidade nacional" e a "recuperação do passado" - principais bases do projeto estadonovista - foram mostrados através de uma sobriedade áspera, e assim sendo, o narrador articulou inteligentemente sua crítica à cultura autoritária e desconstruiu o projeto de nacionalidade desejado pelo Estado Novo.

Por outro lado, não se pode desconhecer que o governo de exceção e a publicação do DIP também possuíam armas e espinhos que lhes garantiam poder de barganha. A cooptação de intelectuais de colorações ideológicas e matizes artísticas diversas, espaço de comunicação com o leitor de amplo alcance, remuneração acima da média e em dia, além de facultar-lhes o acesso aos postos burocráticos no serviço público federal eram armas poderosas. Atraído, como muitos escritores, ao seio da revista, Graciliano Ramos conseguiu alfinetar a ideologia cultural estado-novista do periódico, mas por este também foi espetado. A revista habilmente soube rotular seus textos como documentais, aplicou-lhes a etiqueta de retratos fidedignos de tradições sertanejas e assim colocou-os em consonância com a ideologia cultural da revista e, por extensão, do Estado Novo.

Portanto, não podemos estabelecer Graciliano como vítima desse processo, nem tampouco culpar o governo. Não há altruísmo, inocência ou coerção nesse processo. Ambos, o escritor e o anfitrião da revista, Almir de Andrade, tinham consciência do que ofereciam e do preço a pagar/receber. O cronista fora alertado sobre o que iria escrever - memória e ficção - e o diretor da revista, um dos principais ideólogos do regime de exceção, conhecia não apenas o homem Graciliano, mas também a produção ficcional e o posicionamento político ideológico do convidado. Logo o "acanalhamento" do escritor já era previsível e o uso ideológico dos textos pela revista, esperado.

Apesar do "contrato" entre Almir de Andrade e Graciliano Ramos e a despeito de sua longa permanência na revista, não nos é possível, a partir do que estudamos e pesquisamos, 
afirmar que o cronista foi cooptado ao programa cultural do regime ditatorial comandado por Vargas, nem podemos falar em alinhamento ideológico. No entanto, podemos falar em contradição. Em nosso percurso de averiguação do oficial e do oficioso, vimos que Graciliano Ramos trabalhou para o governo, e não foi apenas um "bico", procurou se adequar aos temas propostos e ao tempo pretérito (espaço e tempo) e também procurou "iludir" o projeto cultural, literário, ideológico da revista, e por extensão do Estado Novo, realizando, apesar das adequações, um discurso em contraversão. Mas o faz de dentro de um espaço ideológico do governo, onde falta ilusão e sobra astúcia. Por isso ele, embora tente, não consegue sair do ideológico, nem tem como negar sua longa permanência nesse aparelho ideológico. A revista classifica seus textos de acordo com o projeto cultural do regime e os coloca em conexão com a ideologia cultural da revista: propagandear os ideais de nacionalidade/realidade brasileira. Portanto, embora se mexendo dentro dos limites impostos, Graciliano não conseguiu ser ideológico e contra-ideológico ao mesmo tempo. Não há como exercer o papel de outsider e insider simultaneamente. Não é possível colaborar com textos, ser bem remunerado e descartar, diminuir essa colaboração ou tentar desqualificar o projeto cultural da revista dentro da revista. É essa a contradição do cronista da Cultura Política: é ideológico e ao mesmo tempo procura, pela subversão do discurso, sair do ideológico.

Em outros termos, ao tempo em que minava o projeto cultural através do uso da ironia, de um retrato cru da realidade sertaneja, colocando o dedo na ferida do atraso e da pobreza e, portanto, realizando um exercício de abuso e provocação ao poder instituído, ele permanecia dentro do espaço ideológico, era bem remunerado e se mantinha nele. Assim, não poderia haver nessa combinação - colaboração remunerada, inversão do discurso panegírico do sertão - um espaço de neutralidade, de não contradição.

\section{Referências}

ANTELO, Raul. Literatura em revista. São Paulo: Ática, 1984.

GARCIA, Nelson Jahr. Estado Novo: ideologia e propaganda política; a legitimação do Estado autoritário perante às classes subalternas. São Paulo: Loyola, 1982.

GARBUGliO, José Carlos et al. Graciliano Ramos. Coleção Escritores Brasileiros Antologia \& Estudos. São Paulo: Ática, 1987.

GOMES, Angela Maria de Castro. A construção do homem novo: o trabalhador brasileiro. In: 
OLIVEIRA, Lúcia Lippi et al. Estado Novo: Ideologia e Poder. Rio de Janeiro: Zahar, 1982.

História e historiadores: a política cultural do Estado Novo. Rio de Janeiro: Editora Fundação Getulio Vargas, 1996.

LIMA, Eli Napoleão de. Euclides da Cunha e o Estado Novo. In: ALMEIDA, Angela M. A.; ZILLY, Berthold; LIMA, Eli Napoleão (org.). De sertões, desertos e espaços incivilizados. Rio de Janeiro: FAPERJ: MAUAD, 2001.

MELO, Ana Amélia M. C. Pensando o Brasil: os escritos de Graciliano Ramos durante o Estado Novo. In: ALMEIDA, Angela M. A.; ZILLY, Berthold; LIMA, Eli Napoleão (org.). De sertões, desertos e espaços incivilizados. Rio de Janeiro: FAPERJ: MAUAD, 2001.

OLIVEIRA, Lúcia Lippi. Tradição e Política: o pensamento de Almir de Andrade. In: OLIVEIRA, L. L. et al. Estado Novo: Ideologia e Poder. Rio de Janeiro: Zahar, 1982.

RAMOS, GRACILIANO. Memórias do cárcere.6 ed. São Paulo: Martins Editora, 1962. 2 v.

RAMOS, GRACILIANO. Linhas tortas. 8 ed. Rio, São Paulo:Record, 1980.

RAMOS, GRACILIANO. Viventes das Alagoas: quadros e costumes do Nordeste. 10 ed. Rio, São Paulo:Record, 1981.

VARGAS, Getúlio. Discurso de posse na ABL. In: Discursos Acadêmicos. Rio de Janeiro: ABL, 2007. tomo III.

VARGAS LLOSA, Mario. Cartas a um jovem escritor: toda vida merece um livro. Rio de Janeiro: Elsevier, 2008.

VELloSO, Mônica Pimenta. Cultura e Poder Político: Uma configuração do campo intelectual. In: OLIVEIRA, L. L. et al. Estado Novo: Ideologia e Poder. Rio de Janeiro: Zahar, 1982. 